\title{
HOSPITAL TAX-EXEMPTION AND THE COMMUNITY BENEFIT STANDARD: CONSIDERATIONS FOR FUTURe POLICYMaKing
}

\author{
Bobby A. Courtney*

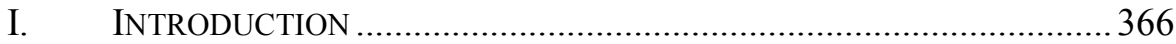

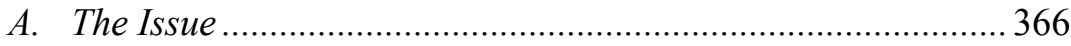

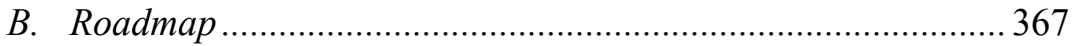

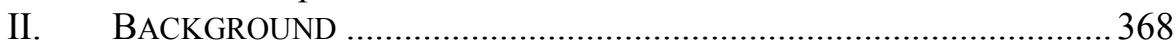 \\ A. Evolution of the Community Benefit Standard......................... 368 \\ 1. The Early Years........................................................ 368

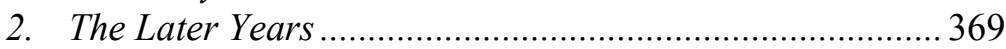 \\ B. Modern Reaction to the Community Benefit Standard ............ 371 \\ 1. The States Weigh In .......................................................... 371 \\ 2. The IRS Takes a Hard Look ............................................... 372

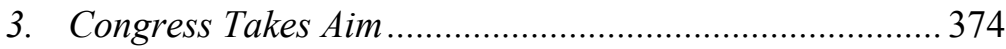

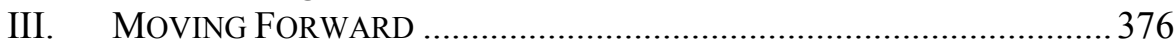 \\ A. Why Does the Community Benefit Standard Matter? .............. 376 \\ B. Is There Really Any Difference Between Nonprofit and \\ For-Profit Hospitals?.......................................................... 377

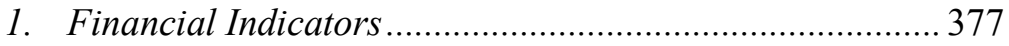

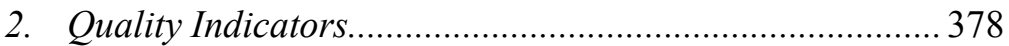

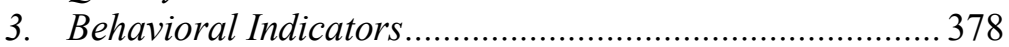

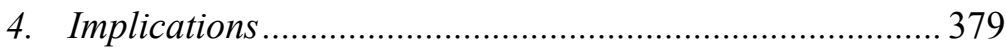 \\ C. Mandatory Charity Care Percentages.................................. 379 \\ D. Medicare Shortfall, Bad Debt, and Community-Building

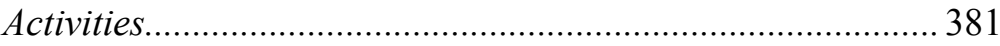 \\ 1. The Current State of Affairs .......................................... 381 \\ 2. Bad Debt \& Medicare Shortfall ....................................... 382

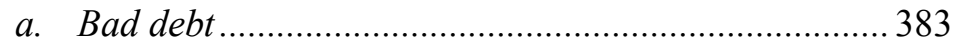 \\ (I) Amount determination....................................... 384 \\ (II) Improved processes........................................... 385

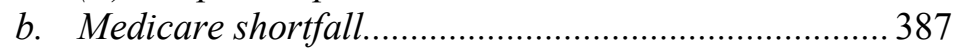

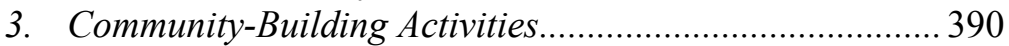

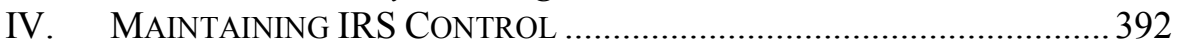

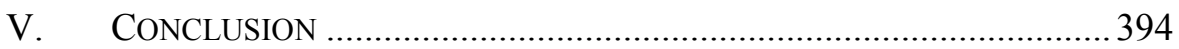

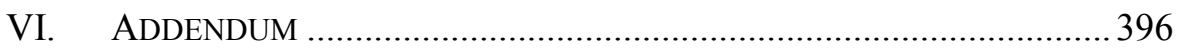

* J.D./M.P.H. Candidate, 2012, Indiana University School of Law-Indianapolis; B.A., 1999, University of Illinois_-Urbana; M.A., 2001, Bradley University. This Note received the 2010, Indiana State Bar Association Health Law Section's Distinguished Writing Award. 


\section{INTRODUCTION}

The Boston Globe recently reported that in 2007, ten of Massachusetts' leading hospital companies received approximately $\$ 638$ million in tax incentives and state borrowing discounts, exceeding the value of "community benefits" (i.e., indigent care and other charity work) they provided by more than $\$ 264$ million that same year. ${ }^{1}$ Without further analysis, this discrepancy appears at odds with a general principle of nonprofit taxexemption; specifically, that "the government's loss of tax revenues is offset by its relief from financial burdens that it would otherwise have to meet with appropriations from public funds, and by the benefits resulting from the promotion of general welfare."2 However, during this same year the largest of these companies provided care to Medicare patients at a loss of approximately $\$ 400$ million, care to Medicaid patients at a loss of nearly $\$ 145$ million, and care to self-pay patients at a loss of over $\$ 40$ million. $^{3}$ Additionally, the company continues to invest significant resources in community-based partnerships aimed at addressing health disparities; programs that improve the health of women through emergency shelter, social support, and educational opportunities; community workforce development programs; and services for homeless adults and veterans. ${ }^{4}$ Should these unreimbursed costs and other community services be considered as part of the tax-exemption calculus? If so, to what extent? Certainly not limited to Massachusetts, this question continues to spur significant debate over the extent to which nonprofit hospitals "deserve" their tax-exempt status.

\section{A. The Issue}

The issue of hospital tax-exemption is particularly important given the over 50 million citizens without health insurance in the United States. ${ }^{5}$ Historically, the uninsured have relied on the charity of private hospitals (i.e., not government owned) for care. ${ }^{6}$ These private hospitals are largely non-

1. Scott Allen \& Marcella Bombardieri, Much is Given by Hospitals, More is Asked, The Bos. Globe, May 31, 2009, at A1.

2. U.S. Gov't Accountability OfFice, GAO-08-880, NonProfit Hospitals: Variation in Standards and Guidance Limits Comparison of How Hospitals Meet COMMUNITY BENEFIT REQUIREMENTS 10 (2008), available at http://www.gao.gov/new.items/ d08880.pdf. See generally 26 C.F.R. § 1.501(c)(3)-1 (2009).

3. Partners HealthCare, Partners HealthCare Community Benefits OvERVIEW 15 (2007), available at http:/www.cbsys.ago.state.ma.us/healthcare/hccbar.asp ?section $=15 \&$ head $2=$ Community + Benefits \&head $3=$ Hospital + and + HMO + Reports $\&$

cbsysappctx $=$ reportfulltext\&cbsyssubctx $=$ download $\&$ filetype $=$ pdf\&reportid $=65 \% 2 \mathrm{D} 2008$.

4. Id. at 5-11.

5. Carmen Denavas-Walt et al., U.S. Census Bureau, P60-238, Income, Poverty, and Health Insurance Coverage in the United States: 2009, at 24 (2010), available at $\mathrm{http}: / / \mathrm{www}$. census.gov/prod/2010pubs/p60-238.pdf.

6. Mark A. Hall \& John D. Colombo, The Charitable Status of Nonprofit Hospitals: 
profit; in fact, "[o]f the 630,000 beds in Medicare-certified community hospitals in the United States in 2003, 68 percent were located in nonprofit hospitals, 16 percent were located in for-profit hospitals, and 15 percent were located in government (nonfederal) facilities."7 Moreover, the American Hospital Association notes that there are over 5,700 hospitals in the United States, more than 2,900 of which are nonprofit, non-governmental facilities. ${ }^{8}$ Given both shrinking reimbursement by government and private payers, and increasingly competitive markets, the cost of unreimbursed care continues to mount and nonprofit hospitals are finding it more difficult to cross-subsidize indigent care (i.e., charity care) using revenues garnered from paying patients. ${ }^{9}$ As such, a perception exists that many nonprofit hospitals do not warrant their tax-exempt status, since their direct charity care figures do not equal the financial benefit these entities receive from said exemption.

\section{B. Roadmap}

This note does not purport to analyze or recommend new constructs upon which charitable exemption should be based; rather, it offers a pragmatic discussion of elements that should be included when considering taxexemption as applied to nonprofit hospitals. To facilitate such a discussion, Part II addresses the evolution of tax-exemption for nonprofit hospitals, criticism of the current standard, as well as State, Internal Revenue Service ("IRS"), and Congressional responses to the issue. Part III suggests that any future standard should exclude a mandatory charity care percentage, yet include bad debt, the unreimbursed cost of Medicare, and hospital "community-building" activities. Finally, Part IV recommends that the locus of control for defining the standard should remain with the IRS.

Toward a Donative Theory of Tax Exemption, 66 WASH. L. REV. 307, 315 (1991). See generally Douglas M. Mancino, Symposium: Health Care and Tax Exemption: The Push and Pull of Tax Exemption Law on the Organization and Delivery of Health Care Services: The Impact of Federal Tax Exemption Standards on Health Care Policy and Delivery, 15 HEALTH MATRIX 5 (2005).

7. Cong. Budget Office, 109th Cong., Pub. No. 2707, Nonprofit Hospitals and THE PROvision OF COMMUNITY BENEFITS 3 (2006), available at http://www.cbo.gov/ftpdocs/ 76xx/doc7695/12-06-Nonprofit.pdf.

8. Steven T. Miller, Comm'r, Tax Exempt and Gov't Entities, Internal Revenue Serv., U.S. Dep't of the Treasury, Remarks Before the Office of the Attorney General of Texas 2 (Jan. 12, 2009), available at http://www.irs.gov/pub/irs-tege/miller_speech_ 011209.pdf.

9. Hall \& Colombo, supra note 6 , at 315 . 


\section{BACKGROUND}

\section{A. Evolution of the Community Benefit Standard}

\section{The Early Years}

The history of American hospital tax-exemption has been widely addressed in legal scholarship. ${ }^{10}$ Hospitals are not per se tax-exempt under the Internal Revenue Code, rather receipt of such benefits is grounded in an organization's designation as "charitable" under $\S 501(\mathrm{c})(3) .{ }^{11}$ Generally speaking, qualification for exemption under this section requires that a hospital: 1) be organized and operated exclusively for charitable purposes; 2) not use any part of its net earnings for the benefit of any private person; and 3 ) adhere to certain statutory limitations regarding legislative lobbying and participation in political campaigns. ${ }^{12}$ One might expect these requirements to include the provision of free health care services; however, charitable is a term of art never expressly defined by Congress. ${ }^{13}$ As such, a hospital's nonprofit status under $\$ 501(c)(3)$ was historically dependent upon an IRS finding that it was "engaged in relief of the poor or distressed . . .."14

In 1956, the IRS announced a substantive rule of charitable purpose. ${ }^{15}$ Specifically, Revenue Ruling 56-185 permitted nonprofit hospitals to charge patients, but conditioned tax-exemption on the provision of charity care "to the extent of [the hospital's] financial ability." 16 The ruling went on to note that a low charity care record is not dispositive; however, the requirement is not met simply because the hospital expects, but does not receive, full payment for services. ${ }^{17}$ Although the Ruling did not provide a formula for assessing a hospital's charity care and the IRS has never taken an official position on how much actual charity care was required, "if a hospital lacked a substantial charity care program, auditing agents almost always recommended denial or revocation of exempt status." 18

10. See generally Jill R. Horwitz, Does Nonprofit Ownership Matter?, 24 YALE J. ON REG. 139 (2007); Jack E. Karns, Justifying the Nonprofit Hospital Tax Exemption in a Competitive Market Environment, 13 WiDENER L.J. 375 (2004); and Daniel M. Fox \& Daniel C. Schaffer, Tax Administration as Health Policy: Hospitals, the Internal Revenue Service, and the Courts, 16 J. Health - Pol'y \& L. 251 (1991) (all articles examine the history of the law of "charity," as well as American charitable tax policy related to nonprofit hospitals).

11. 26 U.S.C. $\S 501(c)(3)(2006)$.

12. John D. Colombo, Are Associations of Doctors Tax-Exempt? Analyzing Inconsistencies in the Tax-Exemption Of Health Care Providers, 9 VA. TAX REV. 469, 474-75 (1990).

13. Id. at 475 .

14. Id.

15. See Rev. Rul. 56-185, 1956-1 C.B. 202, available at http://www.irs.gov/pub/irstege/rr56-185.pdf.

16. $I d$. (alteration in original).

17. Id.

18. John D. Colombo, Symposium: Health Care and Tax Exemption: The Push and Pull of Tax Exemption Law on the Organization and Delivery of Health Care Services: The 
The substantive test established in Revenue Ruling 56-185 remained until 1969, when the IRS announced Revenue Ruling 69-545, presently referred to as the "community benefit standard." 19 Written while Congress was considering Medicare and Medicaid legislation, it has been asserted that this Ruling was a direct response to complaints from the hospital industry that the combination of private insurance and the new public insurance programs would reduce the overall demand for charity care, making it difficult for hospitals to satisfy the IRS's exemption requirement. ${ }^{20}$ The new Ruling stated that the general law of charity considered promotion of health a charitable purpose; therefore, "[a] nonprofit organization whose purpose and activity are providing hospital care is promoting health and may ... qualify as organized and operated in furtherance of a charitable purpose. $" 21$

Revenue Ruling 69-545 further identified five key factors to be considered when determining whether a hospital qualifies for exemption under section 501(c)(3), namely, does the hospital: (1) operate an emergency room open to all persons regardless of ability to pay; (2) provide care to all persons able to pay directly or through insurance; (3) serve a public interest; (4) maintain an open medical staff; and (5) use surplus revenues to improve the quality of care, facilities, medical training, education, and research. ${ }^{22}$ Determinations were to be made after consideration of "all of the relevant facts and circumstances in each case," with the absence of particular factors, or the presence of others, not necessarily being determinative. ${ }^{23}$

\section{The Later Years}

Academics have suggested that the IRS began to undermine its standard almost immediately after adoption. ${ }^{24}$ In 1973, Sound Health Association ("Sound Health"), a "staff model" nonprofit Health Maintenance Organization ("HMO") was denied tax-exemption under section 501(c)(3). ${ }^{25}$ Under this model, Sound Health employed salaried clinicians, contracted with secondary providers, and administered nearly all services at

Failure of Community Benefit, 15 HeAlth Matrix 29, 30 (2005).

19. John M. Quirk, Turning Back the Clock on the Health Care Organization Standard for Federal Tax Exemption, 43 Willamette L. Rev. 69, 74 (2007). See generally Robert S. Bromberg, The Charitable Hospital, 20 CATH. U. L. REV. 237 (1970).

20. Colombo, supra note 18, at 30-31.

21. Rev. Rul. 69-545, 1969-2 C.B. 117, available at http://www.irs.gov/pub/irs-tege/ rr69-545.pdf.

22. $I d$.

23. Id.

24. See generally Colombo, supra note 18; Mancino, supra note 6.

25. Sound Health Ass'n v. Comm'r, 71 T.C. 158, 172 (T.C. 1978) (In 1973, Sound Health opened its clinic to nonmembers on a fee-for-service basis, and began providing emergency services without regard to the patient's ability to pay. Moreover, Sound Health initiated a subsidy program for nonmembers who failed to meet Medicaid's minimum income requirements, yet still could not afford the Association's dues.). 
its own clinic. ${ }^{26}$ Moreover, it provided services to both members and nonmembers regardless of their ability to pay. ${ }^{27}$ Despite this structure and clear Congressional preference for such organizations, ${ }^{28}$ a final IRS ruling declared that Sound Health's members would receive preferential treatment and that a prepayment feature for members did not further a public charitable purpose. ${ }^{29}$ However, the Tax Court disagreed noting that the provision of medical care is a charitable activity and that the tests applied to determine hospital exemption are relevant to HMOs. ${ }^{30}$ The court went on to hold that there was no significant preferential treatment resulting in private benefit to the organization's "insiders," and that membership was "not so limited that the community as a whole [would] not benefit."31

In the early 1990s, the IRS challenged the charitable exemption of another HMO, Geisinger Health Plan ("Geisinger"). ${ }^{32}$ In contrast to Sound Health, Geisinger was organized as a "contractual model" (meaning it maintained provider contracts with third party health professionals $)^{33}$ with a limited charity care program. ${ }^{34}$ Hoping to capitalize on these differences, the IRS's arguments were again rejected by the Tax Court, which held that Geisinger's membership was unlimited, provided a community benefit, and was not operated for private benefit. ${ }^{35}$ However, on appeal, the Third Circuit reversed finding the community benefit was limited to Geisinger members "since the requirement of subscribership remain[ed] a condition precedent to any service." 36 In addition, the plan's charity care offering in the form of a subsidized dues program was miniscule and would only cover thirty-five people, as compared to approximately 70,000 paying members. ${ }^{37}$

Almost ten years after the Geisinger decision, the Tax Court heard a series of cases concerning the tax-exempt status of three Intermountain Health Care ("IHC") System subsidiary HMOs. ${ }^{38}$ In each case, the Tax Court held against a grant of exemption for failure to provide a community

26. Id.

27. $I d$.

28. See Health Maintenance Organization Act of 1973, Pub. L. No. 93-222 (codified as amended at 42 U.S.C. $\S 300 \mathrm{e}(2006)$ ).

29. Sound Health Ass'n, 71 T.C. at 176.

30. Id. at $178-79$.

31. Id. at $189-90$ (alteration in original).

32. Geisinger Health Plan v. Comm'r, T.C.M. (RIA) 91649 (1991).

33. Peter R. Kongstvedt, The Managed Health Care Handbook 38 (Aspen Publishers, 4th ed. 2001) (1985).

34. Geisinger Health Plan, T.C.M. (RIA) 91649 at 18, 32-34.

35. Id. at 36-37.

36. Geisinger Health Plan v. Comm'r, 985 F.2d 1210, 1219 (3d Cir. 1993) (alteration in original).

37. Id. at 1220 .

38. See generally IHC Care v. Comm'r, 82 T.C.M. (CCH) 617 (2001); IHC Group, Inc. v. Comm'r, 82 T.C.M. (CCH) 606 (2001); IHC Health Plans, Inc. v. Comm'r, 82 T.C.M. (CCH) 593 (2001); IHC Health Plans, Inc. v. Comm'r, 325 F.3d 1188 (10th Cir. 2003). 
benefit and specifically highlighted the lack of charity care in the HMO's operations. On appeal, the Tenth Circuit affirmed, noting that IHC provided "virtually no free or below-cost health-care services." 39 Professor John Colombo argues that the position taken by the IRS in Sound Health ran counter to the broad language of Revenue Ruling 69-545, and that "simply providing health care to all paying patients was insufficient to warrant exemption." 40 Moreover, the Third Circuit's decision in Geisinger "signaled that the community benefit test . . . was inadequate to distinguish "charitable' health care from 'non-charitable' health care." 41 These initial cases, coupled with the subsequent IHC rulings, illustrate that something more like "health care plus," arguably a substantial charity care program, is required. $^{42}$

\section{B. Modern Reaction to the Community Benefit Standard}

\section{The States Weigh In}

State income tax laws largely derive from section 501(c)(3) of the Internal Revenue Code; however, state property and sales tax exemptions typically have their own standards. ${ }^{43}$ As such, exemption under the Code does not necessarily entail a state property or sales tax exemption. ${ }^{44}$ The former is of great importance to hospitals given that they "are often highly capitalintensive businesses with significant property holdings." states have historically recognized nonprofit community hospitals as being exempt from property taxes ${ }^{46}$ a series of cases and legislation beginning in 1985 illustrate a growing concern that nonprofit hospitals are not providing charity care sufficient to meet exemption.

In Utah County v. Intermountain Health Care, Inc., the Utah Supreme Court upheld the exemption revocation of several hospitals, noting they had not "demonstrated any substantial imbalance between the value of the services [provided] and the payments it receives apart from any gifts, dona-

tions, or endowments." 47 Specifically, the charity care provided by the hospitals was less than one percent of their gross revenues, and was not in-

39. IHC Health Plans, Inc. v. Comm'r, 325 F.3d 1188, 1200 (10th Cir. 2003).

40. Colombo, supra note 18, at 32.

41. Id. at 34 .

42. Id. at $36-37,40$.

43. John Colombo, Federal and State Tax Exemption Policy, Medical Debt and Healthcare for the Poor, 51 ST. LouIS U. L.J. 433, 436 (2007).

44. Id.

45. $I d$.

46. Id. at 440 .

47. Utah Cnty. By and Through Cnty. Bd. of Equalization v. Intermountain Health Care, Inc., 709 P.2d 265, 274 (Utah 1985) (alteration in original). 
tentionally advertised due to fears that patients would take advantage of it. ${ }^{48}$ Several years later, the Texas Legislature passed a law setting financial guidelines for charity care provided by tax-exempt hospitals. ${ }^{49}$ Although not as stringent as the Texas guidelines, a number of states have also enacted legislation either mandating or making voluntary hospital community benefit reporting (e.g., California, Idaho, Illinois, Indiana, Maryland, and New York). ${ }^{50}$ Most recently, publicity generated by the revocation of two Illinois hospitals' state property tax-exemptions, ${ }^{51}$ resulted in draft legislation establishing debt collection regulation and strict charity care requirements. ${ }^{52}$ While the latter were eventually withdrawn, they would have imposed an obligation on nonprofit hospitals to provide charity care equal to or greater than eight percent of the hospital's total operating costs. ${ }^{53}$

\section{The IRS Takes a Hard Look}

In response to calls for increased transparency in the nonprofit sector by Senators Max Baucus and Chuck Grassley, ${ }^{54}$ the IRS recently revised Form 990, "the primary mechanism used to monitor exempt organizations' compliance with federal tax law." 55 "[C]hanges include[d] an overhaul of

48. Id.

49. Colombo, supra note 43, at 442. See also Tex. Health \& SAfEty Code Ann. $\S \S$ 311.041-311.048 (West 2010).

50. Cal. Health \& Safety Code $\S \S 127350,127355$ (Deering 2010), Idaho Code AnN. § 63-602D (2010); 210 Ill. Comp. Stat. AnN. 76/15, 76/20 (LexisNexis 2010); InD. Code AnN. §§ 16-21-9-4-16-21-0-7 (LexisNexis 2010); MD. Code AnN., Health-Gen. § 19-303 (LexisNexis 2010); N.H. ReV. Stat. AnN. §§ 7:32-e-7:32-g (LexisNexis 2010); N.Y. Pub. Health LaW § 2803-1 (Consul. 2010).

51. In 2004, the Champaign, Illinois County Board of Review recommended revocation of property tax-exemption for Provena Covenant Medical Center in Urbana, Illinois. The Board made a similar recommendation in 2005 for Carle Hospital in Urbana. In both cases, the Board found that the hospitals failed to meet their charity-care obligations. Specifically, both were: 1) charging uninsured patients two to five times what insured patients were charged for the same services; 2) using aggressive collection practices, which included suing patients; 3 ) providing limited charity care (less than one half of one percent of total revenues in one case); and 4) involved in intimate business relationships with directly related forprofit entities. Provena's exemption was eventually revoked by the Illinois Department of Revenue, a decision that was upheld on appeal to the Illinois Supreme Court. See generally Provena Covenant Med. Ctr. v. Dep’t of Revenue, 925 N.E.2d 1131 (Ill. 2010); Hearing on the Tax-Exempt Hospital Sector Before the H. Comm. on Ways and Means, 109th Cong., 9298 (May 26, 2005) (statement of Stan Jenkins, Chairman, Champaign County Board of Review) available at http://frwebgate.access.gpo.gov/cgi-bin/getdoc.cgi?dbname $=109$ _ house hearings\&docid=f:26414.pdf; John Colombo, Hospital Property Tax Exemption in Illinois: Exploring the Policy Gaps, 37 Loy. U. CHI. L.J. 493 (2006).

52. See H.R. 5000, 94th Gen. Assem., Reg. Sess. (Ill. 2006); H.R. 4999, 94th Gen. Assem., Reg. Sess. (Ill. 2006).

53. Colombo, supra note 43, at 444.

54. See Press Release, Sen. Grassley Works to Build Confidence in Nonprofits with Greater Transparency (May 29, 2007), available at http://grassley.senate.gov/news/Article .cfm?customel_dataPageID_1502 $=12581$.

55. Eileen Salinsky, Nat'l Health Policy Forum, The George Washington 
the 'core form' that captures select information regarding exempt organizations' financial status, governance, staffing, and employee compensation, as well as the creation of several schedules which seek to standardize reporting for information that had previously been provided through filer-designed attachments." ${ }^{, 56}$ Schedule H of Form 990 in particular will require nonprofit hospitals to provide the IRS with detailed information, using standardized definitions, describing their charitable efforts beginning in 2009 (reporting tax year 2008). ${ }^{57}$

Schedule $\mathrm{H}$ is organized into six parts, based in large part on voluntary reporting guidelines originally developed by the Catholic Health Association. ${ }^{58}$ Specific reporting sections include: 1 ) charity care and certain other community benefits; 2) community building activities; 3) bad debt, Medicare, and collection practices; 4) management companies and joint ventures; 5) facility information; and 6) supplemental information. ${ }^{59}$ Moreover, Schedule $\mathrm{H}$ provides clear standards with respect to the types of activities reportable as community benefit and how such activities should be reported (costs rather than charges). ${ }^{60}$ Schedule $\mathrm{H}$ does not "provide a bright line standard against which the reported data can be assessed to determine whether the reporting hospital should be tax-exempt or should be taxed." ${ }^{\prime \prime}$

In addition to revising Form 990, the IRS initiated a Hospital Compliance Project in May 2006 to study community benefit and executive compensation. ${ }^{62}$ The project consisted of surveying over 500 nonprofit hospitals, classified by community type, revenue size, as well as health insurance coverage and per capita income of the surrounding area. ${ }^{63}$ Several key findings from the report were as follows: 1) the average percentage of total revenues spent on combined community benefit was nine percent; 2) community benefit expenditures were not evenly distributed, as nine percent of the hospitals, mainly large and urban hospitals, reported sixty per-

Univ., Background Paper No. 67, Schedule H: New Community Benefit Reporting REQUIREMENTS FOR HOSPITALS 4 (2009), available at http://www.nhpf.org/library/ background-papers/BP67_ScheduleH_04-21-09.pdf.

56. Id. (alteration in original).

57. Id.

58. Id. at 6. See generally CATHOlic Health Ass'N Of The U.S., The IRS Form 990, Schedule H: Community Benefit and Catholic Health Care Governance Leaders (2009), available at http://www.chausa.org/WorkArea/linkit.aspx?LinkIdentifier=id\&ItemID $=978$ (The Catholic Health Association has been a proponent of the community benefit role of nonprofit health care providers for over twenty years and worked closely with the Internal Revenue Service in its development of the new reporting requirements.).

59. Internal Revenue Serv., Dep't of the Treasury, OMB No. 1545-0047, SCHEDUle H (Form 990), HospitAls (2010), available at http://www.irs.gov/pub/irs-pdf/ f990sh.pdf.

60. See Miller, supra note 8, at 9-10.

61. Id. at 10 (alteration in original).

62. Internal Revenue Serv., Dep't of the Treasury, IRS Exempt Organizations (TE/GE) Hospital Compliance Project Final Report 1 (2009), available at http://www.irs.gov/pub/irs-tege/frepthospproj.pdf.

63. Id. at $1-3$. 
cent of the community benefit expenditures; 3 ) uncompensated care was the largest component of community benefit at fifty-six percent, and was greatest for critical access, rural, and small hospitals; 4) medical education and training expenditures represented twenty-three percent of the community benefit, research expenditures represented fifteen percent, and community programs six percent; and 5) aggregate profit margin was five percent, with twenty-one percent of hospitals reporting a deficit. ${ }^{64}$ However, the study was not without its limitations given that the data were not independently verified, ${ }^{65}$ and the IRS did not limit what could be included within a reportable category. ${ }^{66}$ As such, expenditures reported by some hospitals may overstate what will actually be reported on the upcoming Schedule $\mathrm{H}$, due to their inclusion of uncompensated care as charges, bad debt, Medicare shortfalls, and private insurance shortfalls. ${ }^{67}$

\section{Congress Takes Aim}

The community benefit standard has come under increased scrutiny by federal lawmakers in recent years. Beginning in 2004, the Subcommittee on Oversight of the House Ways and Means Committee held hearings on hospital pricing, which included discussions related to charity care and the differences in services offered by nonprofit versus for-profit hospitals. ${ }^{68} \mathrm{~A}$ year later, the full Committee held hearings specifically related to nonprofit hospital tax-exemption, ${ }^{69}$ which subsequently resulted in two research reports by the Congressional Budget Office entitled, Nonprofit Hospitals and the Provision of Community Benefits and Nonprofit Hospitals and Tax Arbitrage. The former addresses the type and amount of community benefit provided by nonprofit hospitals, ${ }^{70}$ while the latter examines the use of taxexempt bonds by nonprofit hospitals. ${ }^{71}$ Despite this interest by the House Committee on Ways and Means, Senator Chuck Grassley, ranking member of the Senate Finance Committee, has been the most vocal in his concern that nonprofits may not be deserving of their tax-exempt status.

64. Id. at 3-5.

65. Id. at 2 .

66. Miller, supra note 8 , at 11

67. InTERnAl ReVENUE SERV., supra note 62, at 2.

68. See generally Pricing Practices of Hospitals, Hearing Before the Subcommittee on Oversight of the H. Comm. on Ways and Means, 108th Cong. (2004), available at http://frwebgate.access.gpo.gov/cgi-bin/getdoc.cgi?dbname=108_house_hearings\&docid=f: 99670.pdf.

69. See generally Hearing on the Tax-Exempt Hospital Sector Before the H. Comm. on Ways and Means, 109th Cong. (2005) available at http://frwebgate.access.gpo.gov/cgi-bin/ getdoc.cgi?dbname $=109$ house hearings\&docid=f:26414.pdf.

70. See generally CONG. BUDGET OfFICE, supra note 7.

71. See generally Cong. Budget Office, 109Th Cong., Nonprofit Hospitals And TAX ARBITRAGE (2006), available at http://www.cbo.gov/ftpdocs/76xx/doc7696/12-06HospitalTax.pdf. 
In May 2005, Senator Grassley conducted an inquiry into nonprofit hospital charity care policies, compensation policies, and types of community benefit provided, by sending letters to ten of the largest U.S. nonprofit hospitals requesting that they account for their charitable activities in light of their tax-exempt status. ${ }^{72}$ Results of Senator Grassley's survey demonstrated that nonprofit hospitals generally have no consistent methodology for measuring community benefit. ${ }^{73}$ As a result, the Senator sought a staff report to aid Finance Committee members in the development of proposals to address the issue. ${ }^{74}$ The staff report was released in July 2007 and recommended development of specific standards for hospitals seeking exemption under section 501(c)(3) including, but not limited to, quantitative standards for charity care; limitations on charges billed to uninsured patients; transparency and accountability requirements; and sanctions for failure to comply with requirements under the Section. ${ }^{75}$

In May 2009, pursuant to the Senate Finance Committee's efforts to develop health care reform legislation, Committee Chairman Senator Max Baucus and Senator Grassley distributed a number of policy options for the Committee's consideration. ${ }^{76}$ Among the options proposed was a recommendation to "codify organizational and operational requirements for determining whether a hospital is a charitable organization for purposes of section 501(c)(3) tax-exempt status." "77 Specifically, hospitals would be required to: 1) conduct regular community needs assessments; 2) meet minimum charity care levels; 3 ) provide services regardless of a patient's inability to pay; and 4) "follow certain procedures before instituting collection actions against patients." 78 Exemptions would be allowed for "[c]ertain hospitals that are critical to the communities they serve or which have an independent basis for tax exemption," such as classification as an educational or research organization; however, those not meeting the enumerated requirements would face intermediate sanctions designed to encourage compliance. $^{79}$

72. See Press Release, Grassley Asks Non-profit Hospitals to Account for Activities Related to Their Tax-exempt Status (May 27, 2005), available at http://grassley.senate.gov/ news/Article.cfm?customel_dataPageID_1502 $=12892$.

73. Press Release, Grassley Directs Effort to Ensure More Charitable Care from Nonprofit Hospitals (Sept. 13, 2006), available at http://grassley.senate.gov/news/Article.cfm? customel_dataPageID_1502=9773.

74. Id.

75. See Staff of S. Comm. on Fin. - Minority, 110th Cong., TaX-Exempt HoSPITALS: DisCUSSION DRAFT 2 (Comm. Print 2007), available at http://grassley.senate.gov $/$ releases/2007/07182007.pdf.

76. See S. Fin. Comm., 111th Cong., Financing Comprehensive Health Care Reform: Proposed Health System Savings and Revenue Options (Comm. Print 2009), available at http://finance.senate.gov/download/?id=d8b0f79c-ea88-49cb-96f8-1d6cf6c5 b577.

77. Id. at 33

78. Id.

79. Id. at 33-34. 
On September 22, 2009, the Chairman's Mark was released entitled, America's Healthy Future Act of 2009. ${ }^{80}$ The Mark included requirements for community needs assessments, financial assistance policies, charge limitations, collection policies, as well as reporting and disclosure; however, a charity care standard and a broad sanctions scheme were left out. ${ }^{81}$ In response, Senator Grassley noted that a mandatory charity percentage requirement would likely "become a ceiling, not a floor" and, therefore, additional study was necessary to devise a formula that maximizes nonprofit hospital expenditures for charitable purposes. ${ }^{82}$ According to Steven T. Miller, Commissioner, Tax Exempt and Government Entities at the IRS, "Senator Grassley continues to discuss the possibility of introducing legislation in this area."

\section{MOVING FORWARD}

\section{A. Why Does the Community Benefit Standard Matter?}

A 2006 Congressional Budget Office report estimated that the value of major tax-exemptions provided to nonprofit hospitals through federal, state, and local governments was approximately $\$ 12.6$ billion in $2002 .{ }^{84}$ This figure consists of $\$ 2.5$ billion in federal corporate income tax-exemptions, $\$ 1.8$ billion in federal tax-exempt-bond financing, $\$ 1.8$ billion in charitable contributions (federal), $\$ 500$ million in state corporate income tax exemptions, $\$ 2.8$ billion in state and local sales tax exemptions, and $\$ 3.1$ billion in local property tax exemptions. ${ }^{85}$ Moreover, according to recent IRS data concerning public charity tax filings, "nonprofit hospitals accounted for revenues of $\$ 451.3$ billion ( $41.6 \%$ of total public charity revenues) and assets of $\$ 551.6$ billion (28.5\% of total public charity assets)." 86 Given these figures, it is no surprise that one would question the extent to which nonprofit hospitals are earning their charitable status. Nevertheless, in recent years, legal scholarship ${ }^{87}$ and congressional efforts ${ }^{88}$ have, for the reasons

80. America's Healthy Future Act of 2009, S.1796, 111th Cong. (2009), available at http://frwebgate.access.gpo.gov/cgi-bin/getdoc.cgi?dbname=111_cong_bills\&docid=f:s1796 pcs.txt.pdf. Chairman's Mark is a "[r]ecommendation by committee (or subcommittee) chair of the measure to be considered in a markup, usually drafted as a bill." Chairman's Mark/Staff Draft, THECAPITOL.NET, http://www.thecapitol.net/glossary/c.htm\#Chairman's\% 20Mark/Staff\%20Draft (last visited Mar. 17, 2011).

81. Id. See generally S. Fin. Comm., supra note 76.

82. Press Release, Grassley Welcomes Non-profit Hospital Provisions in Chairman's Health Care Reform Bill (Sept. 17, 2009), available at http://grassley.senate.gov/news/ Article.cfm?customel_dataPageID_1502=23094.

83. Miller, supra note 8, at 8.

84. Cong. Budget OfFice, supra note 7, at 5.

85. Id.

86. Horwitz, supra note 10 , at 146.

87. See Terri L. Brooks, Billions Saved in Taxes While Millions Underserved - What 
explained below, incorrectly suggested legislation aimed at increasing nonprofit hospital responsibility in order to maintain tax-exempt status.

\section{B. Is There Really Any Difference Between Nonprofit and For-Profit Hospitals?}

Despite being bound by section 501(c)(3)'s qualifications for taxexemption, most notably the non-distribution constraint ${ }^{89}$ a perception exists that nonprofit hospitals are no different than their for-profit counterparts, and therefore are undeserving of exemption. As such, numerous studies have considered whether ownership type influences financial performance, patient outcomes, and likelihood of providing certain services.

\section{Financial Indicators}

In 2006, the National Bureau of Economic Research conducted a meta-analysis of empirical literature investigating the effect of hospital ownership on financial performance (e.g., cost, revenue, profit margin, and efficiency). ${ }^{90}$ Their analysis found that diverse results among the literature could be explained largely by "differences in authors' underlying theoretical frameworks, assumptions about the functional form of the dependent variables, and model specifications." $" 91$ Those studies using weaker methods and functional forms tended to predict greater divergence in financial performance among ownership types; however, combined estimates suggested for-profit hospitals generate greater revenue, albeit modest in terms of economic significance, than their nonprofit counterparts. ${ }^{92}$ Moreover, a summary of several studies on gross uncompensated care data illustrates little difference between nonprofit and for-profit hospitals, as well as "little difference between pre- and post-conversion levels of charity care in nonprofit to for-profit conversion transactions." 93

Has Happened to Charitable Hospitals?, 8 Hous. Bus. \& TAX L. J. 391 (2008); Laura L. Folkerts, Do Nonprofit Hospitals Provide Community Benefit? A Critique of the Standards for Providing Deservedness of Federal Tax Exemptions, 34 IOWA J. CoRP. L. 611 (2009).

88. See generally STAFF OF S. COMM. ON Fin. - MinORITY, supra note 75; S. Fin. Comm., supra note 76.

89. See generally Henry B. Hansmann, The Role of Nonprofit Enterprise, 89 YALE L. J. 835 (1980) (noting that nonprofit organizations are barred from distributing net earnings).

90. Karen Eggleston et al., Hospital Ownership and Financial Performance: A Quantitative Research Review 2 (Nat'l Bureau of Econ. Res. Working Paper No. 11662, 2005), available at $\mathrm{http} / / / \mathrm{www}$. nber.org/papers/w11662.

91. Id. at 2 .

92. Id. at 1 .

93. Colombo, supra note 18 , at 49. 


\section{Quality Indicators}

Regarding the effect of hospital ownership on quality of care, a vast body of literature provides conflicting evidence. ${ }^{94}$ Based on a quantitative review of studies conducted since 1990, researchers indicate that divergent results are largely based on analytic methods. ${ }^{95}$ Specifically, study features such as "disease or outcome studied, whether or not the study adjusted for patient comorbidities, and data sources" tend to explain the differences among attempts to compare patient outcomes between nonprofit and forprofit hospitals. ${ }^{96}$ Moreover, researchers "found no systematic differences in estimated ownership effects between studies that did and did not examine ownership conversions," and "regions covered explained little of the variation in studies of patient outcomes . . ..,97

\section{Behavioral Indicators}

An article by Professor Jill Horwitz demonstrates that, "hospital types differ in their provision of medical services because they are more or less profit-seeking . . ." 98 In other words, hospitals provide services based on their overall goals and objectives. With respect to consistently profitable services such as open-heart surgery, for-profits are more likely than nonprofits to offer such services. ${ }^{99}$ For consistently unprofitable services, such as psychiatric emergency care, data illustrate the exact opposite, in that forprofits are less likely than nonprofits to provide such services. ${ }^{100}$ Finally, concerning services with variable profitability such as home health care, "for-profit responsiveness to financial incentives is strong and quick - likely because for-profits are relatively more profit-seeking ...."101 Criticism is often leveled at nonprofit hospitals for this type of market behavior, as if they are undeserving of their tax-exempt status "merely because the market requires that sound business strategies be employed by all entities seeking to survive, if not thrive." 102

94. Karen Eggleston et al., Hospital Ownership and Quality of Care: What Explains the Different Results 2 (Nat'l Bureau of Econ. Res. Working Paper No. 12241, 2006), available at http://www.nber.org/papers/w12241.

95. Id. at 16 .

96. Id.

97. Id. at 17 .

98. Horwitz, supra note 10 , at 171 .

99. Id. at 171-72.

100. Id. at 173-74.

101. Id. at 174 .

102. Karns, supra note 10, at 494. 


\section{Implications}

The above assessment demonstrates that traditional measures of comparison show little difference between for-profit and nonprofit hospitals. However, managerial behaviors have been shown to differ. ${ }^{103}$ For example, nonprofit hospitals may be more likely to cross-subsidize unprofitable services, thereby improving access in their communities. These behavioral indicators not only demonstrate commitment to a purpose far more beneficent than simply the "promotion of health" as proscribed in Revenue Ruling $69-545,{ }^{104}$ they also provide substantial support to justify nonprofit hospitals' "deservedness" of tax-exempt status.

\section{Mandatory Charity Care Percentages}

As discussed in Part II, the IRS and the Tax Court have implicitly required something more than the broad dictates of Revenue Ruling 69-545, something akin to "health care plus" as described by Professor Colombo. ${ }^{105}$ Moreover, several states have enacted legislation requiring hospitals to provide fixed percentages of charity care. ${ }^{106}$ While credible arguments exist to support such a requirement, ${ }^{107}$ this theory of tax-exemption is wrong for a number of reasons.

First, an underlying rationale for awarding a hospital tax-exempt status is to relieve the government of a financial burden that would otherwise require the appropriation of public funds. ${ }^{108}$ This purpose should not presume that free care be the basis of exemption, as community health can be promoted through any number of activities. Expressed another way, solely focusing on the amount of charity care provided by a hospital "bears no logical relationship to the needs of a particular community."109 For example,

103. Horwitz, supra note 10 , at 159.

104. See Rev. Rul. 69-545, 1969-2 C.B. 117, available at http://www.irs.gov/pub/irstege/rr69-545.pdf.

105. Colombo, supra note 18 , at 36-37, 40 .

106. See generally ALA. CODE $\S 40-9-1(2)$ (LexisNexis 2010) (treatment of charity patients must constitute at least $15 \%$ of the hospital's business); TEX. HEALth \& SAFETY CODE ANN. § 311.045(b)(1) (West 2010) (a level reasonably related to community needs, an amount equal to one hundred percent (minimum) of the hospital's tax-exempt benefits, excluding federal income tax, or a combined amount equal to five percent (minimum) of the hospital's net patient revenue).

107. See Gabriel O. Aitsebaomo, The Nonprofit Hospital: A Call for New National Guidance Requiring Minimum Annual Charity Care to Qualify for Federal Tax Exemption, 26 CAmpBell L. Rev. 75 (2004); Folkerts, supra note 87; Cecilia M. Jardon McGregor, The Community Benefit Standard for Non-Profit Hospitals: Which Community, and For Whose Benefit, 23 J. ContemP. HeAlth L. \& Pol'y 302 (2007).

108. N. Keith Emge, Jr., Nonprofit Hospitals and the State Tax Exemption: An Analysis Of the Issues Since Utah County V. Intermountain Health Care, Inc., 9 VA. TAX REV. 599, 604 (1990).

109. Kevin B. Fischer, Tax Exemption and the Health Care Industry: Are the Challeng- 
suppose Hospital A spends $\$ 20$ million dollars providing free care to indigent patients, and Hospital B spends \$20 million dollars subsidizing a burn unit and emergency mental health services. While the benefit of free care may be directly observable, assessing the absolute value of cross-subsidized service cannot easily be determined (e.g., Hospital B may be located in a community where access to a burn unit or emergency mental health services is compromised due to geographic availability.).

Second, requiring a fixed amount of charity care may excessively burden smaller or independent hospitals located in rural or lower socioeconomic areas. ${ }^{110}$ For example, disproportionate share hospitals may already face heightened financial risk given the number of indigent patients they care for. ${ }^{111}$ Were these facilities mandated to provide a larger percentage of charity care, many would struggle further, or perhaps be forced to close. ${ }^{112}$ By contrast, multi-hospital systems may be able to avoid community benefit disclosure at individual hospitals by reporting community benefit at an aggregate level, which makes it difficult to determine the amount of charity care provided to particular communities, ${ }^{113}$ and may even conceal lower levels of charity care provided in more affluent settings. ${ }^{114}$

Finally, as the IRS Exempt Organizations (TE/GE) Hospital Compliance Project Final Report illustrates, there is no consistently applied formula used by hospitals to assess their community benefit activities. ${ }^{115}$ Even in states where community benefit reporting has been made mandatory, requirements vary. ${ }^{116}$ While the new IRS Form 990 will allow for collection of this information using a standard set of definitions, significant "methodological concerns remain that may influence the analytic value and comparability" of this information. ${ }^{117}$ Specifically, differences in provider type (i.e., size, structure, and scope) and variations in cost accounting methods may have direct implications for assessing the provision of charity care. ${ }^{118}$

es to Tax-Exempt Status Justified?, 49 VAND. L. REV. 161, 194 (1996).

110. See Kevin M. Wood, Legislatively-Mandated Charity Care for Nonprofit Hospitals: Does Government Intervention Make any Difference?, 20 REV. LiTiG. 709, 736 (2001).

111. Disproportionate Share Hospitals receive adjustment payments from CMS based on service to a significantly disproportionate number of low-income patients. See 42 C.F.R. $\S 412.106$ (2010).

112. See Stacey Kramer, Philanthropic Pains: The Push to Implement Charity Care and Community Benefit Mandates is Gaining Speed, but will it Hurt Hospitals?, HealthCARE INFORMATICS, Winter 2008, at 66A.

113. Jack Hanson, Access to Health Care Symposium Article: Are We Getting our Money's Worth? Charity Care, Community Benefits, and Tax Exemption at Nonprofit Hospitals, 17 Loy. CONSUMER L. REV. 395, 407 (2005).

114. Lisa Kinney Helvin, Note: Caring for the Uninsured: Are Not-for-Profit Hospitals Doing Their Share?, 8 Yale J. HeAlth PoL'y L. \& EThics 421, 455 (2008).

115. See generally InTERNAL REVEnUE SERV., supra note 61.

116. SALINSKY, supra note 55, at 16.

117. Id. at 21-22.

118. Id. at 22. (Criticism also exists regarding filers' ability to exclude offsetting grant revenues from community benefit calculations; however, this concern is not being addressed, as it does not directly relate to an assessment of charity care.). 
Concerning differences in provider type, the IRS identifies filing organizations by Employer Identification Number. ${ }^{119}$ Data will be reported by multi-hospital systems, as well as individual hospitals, which "will make it difficult to compare activities across various provider types and may complicate efforts to analyze Schedule $\mathrm{H}$ filings in concert with other data sources, such as Medicare Cost Reports and Medicaid DSH reporting." 120 While Schedule $\mathrm{H}$ eliminates the use of charge-based accounting practices in assessing the value of community benefit, filers continue to have flexibility in determining the cost of services (e.g., cost-to-charge ratios, internal cost accounting systems, etc.). ${ }^{121}$ These differences in costing methods "are likely to yield varying estimates of costs and the validity of some approaches may ultimately be disputed."122

Given the foregoing reasons, and the fact that the IRS has historically avoided a mechanical formula for determining whether a nonprofit hospital has met its responsibility under the community benefit standard, it is reasonable to assert that a fixed percentage requirement for charity care could not presently be applied consistently across the industry.

D. Medicare Shortfall, Bad Debt, and Community-Building Activities

\section{The Current State of Affairs}

The community benefit standard allows nonprofit hospitals some degree of latitude in determining what services and activities constitute community benefit. As a result, significant variation exists in the type and amount of benefits reported. ${ }^{123}$ The U.S. Government Accountability Office ("GAO") recently reviewed guidance provided to nonprofit hospitals from five sources, including government agencies (i.e., Centers for Medicare \& Medicaid Services) and health care industry groups (i.e., the American Hospital Association, the Catholic Health Association, VHA (formerly Voluntary Hospitals of America), and the Healthcare Financial Management Association). ${ }^{124}$ The GAO's review found that consensus existed among sources to include charity care, the unreimbursed cost of Medicaid and other means-tested government programs, and the costs associated with a number of "other activities" (e.g., health professions education, medical research, subsidized health services, etc.) in a definition of community ben-

119. Id. at 21 .

120. Id. at 21-22.

121. Id. at 22 .

122. Id.

123. U.S. Gov'T AcCountability OfFice, supra note 2, at 7.

124. Id. at 4-5. 
efit. ${ }^{125}$ However, debate continues over the inclusion of bad debt, the unreimbursed cost of Medicare, and costs associated with "community building activities" (e.g., housing programs, leadership development for community members, workforce development, etc.) in this definition. ${ }^{126}$

\section{Bad Debt \& Medicare Shortfall}

Bad debt is generally defined as uncollectible patient accounts. ${ }^{127}$ For example, if a patient's bill is $\$ 5,000$, and the hospital only expects to collect $\$ 500$, the bad debt amount is $\$ 4,500$. Similarly, the unreimbursed cost of Medicare, referred to as a "shortfall," is defined as the difference between a hospital's cost to care for a Medicare beneficiary and the reimbursement received. ${ }^{128}$ For example, if it costs a hospital $\$ 5,000$ to care for a Medicare patient, yet the diagnosis-related group ("DRG") payment is only $\$ 4,500$, the shortfall amount is $\$ 500$. Both bad debt and shortfall are shown on hospital financial statements in an amount equal to the charges being written off. ${ }^{129}$ Of the twenty-three states that have enacted mandatory charity care reporting, fifteen allow for reporting of bad debt and/or Medicare shortfall. ${ }^{130}$

Regarding bad debt, the Catholic Healthcare Association ("CHA"), VHA, and the Healthcare Financial Management Association ("HFMA") recommend exclusion of this loss in a definition of community benefit. ${ }^{131}$ CHA and VHA maintain that "hospitals have the responsibility to better identify patients eligible for charity care, and thus distinguish charity care from bad debt." 132 Likewise, HFMA encourages hospitals to design charity care policies that provide direction for assessing eligibility when patients provide insufficient information to make a formal determination. ${ }^{133}$ In contrast, the American Hospital Association ("AHA") recommends inclusion of bad debt in a definition of community benefit, asserting that low-income patients represent the majority of uncollectible accounts and would qualify for charity care were the appropriate documentation available. ${ }^{134}$ The IRS and the Centers for Medicare and Medicaid Services ("CMS") have not tak-

125. Id. at 7, 29, 49-51.

126. Id. at 7, 29, 49. See generally Internal Revenue Serv., DeP'T of the Treasury, Publication 535, CAT. No. 15065Z, Business ExPENSES, (2009), available at http://www.irs.gov/pub/irs-pdf/p535.pdf (providing a comprehensive discussion of business bad debt.).

127. U.S. Gov't ACCOUNTABILITy OfFICE, supra note 2, at 19.

128. Id. at 6 n. 21 .

129. Telephone Interview with Ken J. Harbaugh, Chief Fin. Officer, OSF Saint Francis Med. Center (Jan. 4, 2010).

130. SALINSKY, supra note 55, at 16.

131. U.S. Gov'T ACCOUNTABILITy OfFICE, supra note 2, at 20.

132. Id.

133. Id. at 20-21.

134. Id. at 21 . 
en a position on the issue; however, both utilize reporting instruments that permit hospitals to estimate the amount of bad debt attributable to lowincome patients. ${ }^{135}$

Concerning treatment of Medicare shortfalls, CHA and VHA recommend exclusion of shortfall losses in a definition of community benefit, citing concerns over hospital inefficiency, as opposed to underpayment. ${ }^{136}$ Further, because nonprofit and for-profit hospitals compete to attract Medicare patients, service to this population is not a differentiating feature. ${ }^{137}$ By comparison, AHA recommends inclusion of shortfall losses in a definition of community benefits citing Medicare's lack of full compensation for hospital costs and the large number of low-income beneficiaries. ${ }^{138}$ HFMA recommends that individual hospitals consider their specific financial status when deciding whether to include shortfall losses in a reporting of community benefit. ${ }^{139}$ The IRS has not taken a position on the issue; however, Schedule $\mathrm{H}$ requires that hospitals report Medicare revenue and cost information separate from traditional community benefit activities, and allows them to explain what portion of these costs they feel should be included as community benefit. ${ }^{140}$ Similarly, CMS has not officially taken a position, ${ }^{141}$ but it does collect information on hospitals' unreimbursed costs. ${ }^{142}$

\section{a. Bad debt}

Inclusion of bad debt in a definition of community benefit is of great significance to nonprofit hospitals given that many report losses in substantial amounts as compared to charity care. ${ }^{143}$ Based on 2004 data, hospitalspecific bad debt was estimated to be between $\$ 26$ billion and $\$ 30$ billion annually, with research suggesting a two to four percent increase in hospitals' bad debt expense, as a percentage of revenue, by 2012. ${ }^{144}$ Further, it is often impossible to disentangle bad debt from charity care, as more than ninety percent of hospitals state that at least some portion of their bad debt consists of accounts that could be classified as charity care had the patients

135. Id.

136. Id. at 24 .

137. Id.

138. Id. at 24-25.

139. Id.

140. Id. at 25 .

141. Id.

142. Internal Revenue Serv., Dep'T of the Treasury, OMB No. 1545-0047, SCHEDUle H (FORM 990), HospitAls (2010), available at http://www.irs.gov/pub/irspdf/f990sh.pdf.

143. U.S. Gov't ACCOUNTABILITy OfFice, supra note 2, at 23.

144. Nick A. LeCuyer \& Shubham Singhal, Overhauling the US Health Care Payment System, THE MCKINSEY QUARTERLY, June 2007, at 4, available at https://www.tipaaa.com/ pdf/Overhauling $\% 20$ the $\% 20$ US $\% 20$ Health $\% 20$ Care $\% 20$ Payment $\% 20$ System-McKinsey $\%$ 20Report.pdf. 
been properly identified. ${ }^{145}$ As such, a compromise position exists whereby a lesser amount of bad debt could be included in a nonprofit hospital's accounting of charity care. Moreover, this inclusion could be made contingent upon the provider's adoption of systems to better address "administrative inefficiencies." The following provides two examples of how this lesser amount could be determined, and then considers a number of "payer identification" processes.

\section{(I) Amount determination.}

First, bad debt figures could be included in a definition of charity care, calculated as costs rather than charges. Not only does the AHA advocate this position, ${ }^{146}$ but also cost information is being requested on Schedule H. ${ }^{147}$ This inclusion would alleviate the potential for bias that exists when using charge data to make comparisons among hospitals, particularly those with different payer mixes. ${ }^{148}$ For example, comparisons of DRGs across hospitals often show "similar costs per case but different markup rates reflected in their charges." late the true "cost" of hospital services, including total Medicare allowed charges, Medicare payment, and cost-to charge ratios ("CCR"). ${ }^{150}$ The latter, favored by most researchers, requires an analysis of hospital cost reports and claims data to determine the relationship between Medicareallowable costs and hospital charges. ${ }^{151}$ While all of the aforementioned methods have limitations, research suggests that departmental CCRs are most representative of a hospital's true cost. ${ }^{152}$ These costs could be further limited to "variable costs," as opposed to being calculated on a fully allocated basis, which would include an apportionment of the hospital's "fixed costs." Variable costs represent those costs that change according to output

145. PricewaterhouseCooper's Health Research Inst., Acts of Charity: Charity CARE Strategies FOR HoSPITALS IN A CHANGING LANDSCAPE 10 (2005), available at http://pwchealth.com/cgi-local/hregister.cgi?link=reg/charitycare.pdf; see also Press Release, Connance, Research Indicates One-Third of Patient Bad Debt Misclassified, Should be Charity; Significant Opportunity to Demonstrate Community Benefit (Mar. 24, 2009).

146. See Am. Hosp...Ass'n, Uncompensated Hospital Care Cost Fact Sheet 2 (2008), available at $\mathrm{www}$.aha.org/aha/content/2008/pdf/08-uncompensated-care.pdf.

147. INTERNAL REVENUE SERV., supra note 59.

148. See generally The Lewin Group, No. 05-4, A Study of Hospital Charge Setting Practices, (2005), available at http://www.medpac.gov/documents/Dec05 Charge_setting.pdf (discusses the manner in which hospitals establish charges, as well as the relevance of charges given advent of the prospective payment system).

149. Bernard Friedman et al.,Practical Options for Estimating Cost of Hospital Inpatient Stays, 29 J. HeAlth CARE Fin. 1, 1-2 (2002).

150. Faith M. Asper, Research Data Assistance Ctr., TN-008, Using Medicare Hospital Cost Reports Cost-to-Charge Ratios in Research 1 (2009), available at http://www.resdac.umn.edu/Tools/TBs/TN-008_UsingCCRsinResearch_508.pdf.

151. Id.

152. $I d$. 
and are saved if the hospital does not provide a service (e.g., medications, disposable supplies, etc.). ${ }^{153}$ Fixed costs represent those costs that do not change according to output, and are not saved if the hospital does not provide a service (e.g., bricks and mortar, equipment, salaried labor costs, etc.). ${ }^{154}$ This conservative methodology would ensure the highest degree of credibility, as the majority of hospital service costs are fixed. ${ }^{155}$

Second, the Taxation and Health Law Sections of the American Bar Association ("ABA") note that separation of charity care from bad debt is often problematic due to audit guidelines, which may be interpreted to require proof of charity care eligibility that is impractical for hospitals to produce. $^{156}$ For example, a poor patient presenting in an emergency department is not always in a position to provide income or asset documentation sufficient to determine his or her eligibility for charity care, nor does this patient have incentive to do so after receiving treatment. ${ }^{157}$ Therefore, the ABA recommends that the IRS consider a flexible standard that allows hospitals to "recognize the amount of charity care they have provided which, after reasonable efforts, cannot be documented with certainty as charity care without unreasonable cost." "158 One such method would be to presumptively include a percentage of bad debt that corresponds to the number of persons within a hospital's service area that might generally be eligible for free care based on the hospital's charity care policy. ${ }^{159}$

\section{(II) Improved processes.}

Initially, nonprofit hospitals could be required to adopt and publish charity care policies in accordance with IRS-devised guidelines. While no single "approved" model exists, a number of recommendations have been made both within and without government. ${ }^{160}$ For example, the Senate Fi-

153. Ginevra G. Ciavarella et al., Distribution of Variable vs. Fixed Costs of Hospital Care, 281 JAMA 644, 644 (1999).

154. Id. at 646 .

155. Id.

156. Am. Bar Ass'n Section Of Taxation And Health law Section, Comments CONCERning Discussion Draft OF REDESIGNed Form 990 For TAX-Exempt ORGANIZATIONS, 66-67 (2007), available at http://www.abanet.org/health/04_government sub/media/Form990_TaxExemptOrgs_071004.pdf [hereinafter AM. BAR Ass'N].

157. Id. at 67.

158. Id.

159. Id.

160. See generally StAFF OF S. COMM. ON Fin. - MinORITY, supra note 75; P\&P Board Sample 501(c)(3) Hospital Charity Care Policy and Procedures, HealthCARE Fin. Mgmt. Ass'N, http://www.hfma.org/Templates/InteriorMaster.aspx?id=240 (last updated Dec. 2010) [hereinafter HFMA P\&P]; HealthCARE Fin. MgMt Ass'N, A RePort FROM the PAtient Friendly Billing Project (2005), available at hfma.org/HFMAInitiatives/patient-friendly-billing/PFB-2005-Uninsured-report/; ILl. HoSP. Ass'N \& METRO. Chi. Healthcare Council, Report of the Task Force on Charity Care and COLleCtion PRACTICES FOR THE UninsuRED (2003), available at 
nance Committee staff has recommended a minimum eligibility threshold of less than one hundred percent of the federal poverty level, citing the percentage as "a common standard for nonprofit hospitals." I61 In addition, they suggested extensive publication of charity policies, written in plain English and in multiple languages as necessary within a community. ${ }^{162}$ More recently, HFMA published a "model" policy that did not mandate a specific minimum eligibility threshold, but suggested services be made available on a sliding fee scale according to financial need, using federal poverty guidelines. ${ }^{163}$ The policy further recommended an application process considering patients' personal and financial information; the use of credit scoring or other publicly available data to determine ability to pay; the use of reasonable efforts to determine alternative public or private funding; consideration of patients' available assets and other available resources; and review of the patients' outstanding accounts receivable and payment history. ${ }^{164}$ A number of other "presumptive financial assistance" criteria (e.g., food stamp eligibility, residence in low income/subsidized housing, etc.) are also recommended when supporting documentation is insufficient. $^{165}$

Next, adoption of HFMA Principles and Practices Board Statement 15, "which provides instructions for record keeping, valuation, and disclosure of charity care and bad debts on audited financial statements," allow nonprofit hospitals to better distinguish between charity care and bad debt. Board Statement 15 exists as a sample policy for presumptively enrolling patients in hospital charity-care programs ${ }^{167}$ and revised Form 990 requests information regarding whether hospitals have adopted the Statement. ${ }^{168}$ This consistency makes it more likely that nonprofit hospitals will begin to adopt the Statement as a "best practice" standard for accounting and reporting uncompensated care.

Finally, hospitals could begin referring to "external sources, such as zip codes in conjunction with per-capita income data, credit reports, and migrant worker status," in making charity care determinations; a practice that may help estimate the portion of bad debt more accurately attributed to charity care. ${ }^{169}$ As an example, BJC HealthCare recently conducted an extensive analysis of zip code data and found that two-thirds ( $\$ 85$ million) of

http://www.nonprofithealthcare.org/resources/charitycare.pdf; CAL. HEALTHCARE Ass'N, Key Steps Checklist for Developing or Revising a Hospital Charity Care Policy (2004), available at http://www.aha.org/aha/content/2004/pdf/CHAchecklistcharitycare.pdf.

161. STAFF OF S. COMM. ON Fin. - MiNORITY, supra note 75, at 7 n.11.

162. Id. at 6 .

163. HFMA P\&P, supra note 160 , at 3,7 .

164. Id. at 4.

165. Id.

166. SALINSKY, supra note 55, at $17,19$.

167. Melanie Evans, Making Good on Bad Debt, Modern HealthCARe, January 4, 2010 , at 32 .

168. INTERNAL REVENUE SERV., supra note 59.

169. U.S. Gov'T ACCOUNTABILITY OfFICE, supra note 2, at 21 n.53. 
its $\$ 125$ million in bad debt was attributed to patients that would have been eligible for charity care under the organization's existing policy, raising the system's total community benefit (as a percentage of overall expenses) nearly three percent. ${ }^{170}$ Many facilities are also using screening software, directly integrated with existing information systems, to determine self-pay patients' eligibility for charity or public funding upon admission or after scheduling. ${ }^{171}$ Features range from eligibility verification and bill estimation, to identification of alterative sources of financial assistance and enhanced third-party payer connectivity. However, these applications can require significant investment in information technology, and may not be realistic options for all facilities. ${ }^{172}$

\section{b. Medicare shortfall.}

Although participation in Medicare is voluntary, caring for Medicare beneficiaries is a condition for tax-exemption under Revenue Ruling 69$645,{ }^{173}$ and very few hospitals can elect not to participate in the public program given the large percentage of care provided to older patients. ${ }^{174}$ These considerations make clear why inclusion of Medicare shortfall in a definition of community benefit is of great importance to nonprofit hospitals. Again, a compromise position exists, whereby a lesser amount of Medicare shortfall could be included in a nonprofit hospital's accounting of charity care, expressed as variable and/or fixed costs, rather than charges. ${ }^{175} \mathrm{Sev}$ eral practical arguments militate in favor of this position.

Foremost, Medicare was not designed as a complete benefit. Beneficiaries are responsible for deductibles, coinsurance, and copayments under "Part A" (i.e., inpatient hospital coverage), ${ }^{176}$ and monthly premiums, annual deductibles, and coinsurance for most services under "Part B" (i.e., physician and outpatient coverage). ${ }^{177}$ As the program has no limit on beneficiaries' coinsurance responsibility, those with chronic health condi-

170. Evans, supra note 167, at 32.

171. See Healthcare Scoring System Allows Hospitals To Increase Charity Care, L. \& Health Wkly., Jan. 2, 2010, at 834; Orlando Health, Saint Vincent Catholic Medical Centers, University of Maryland Medical System and Wheaton Franciscan Healthcare Adopt MedeAnalytics' Patient Access Intelligence (PAI) in 2009, Bus. WIRE, Dec. 23, 2009; VHA Inc Names Relayhealth a Supplier of Financial Clearance Services, HosP. Bus. WK., Aug. 16,2009 , at 74 .

172. Telephone Interview with Ken J. Harbaugh, supra note 129.

173. Rev. Rul. 69-545, 1969-2 C.B. 117, available at http://www.irs.gov/pub/irstege/rr69-545.pdf.

174. Am. Hosp. Ass'n, Underpayment By Medicare And Medicaid Fact Sheet 1 (2009), available at www.aha.org/aha/content/2009/pdf/09medicunderpayment.pdf.

175. AM. Hosp. Ass'N, supra note 146, at 3 (The American Hospital Association does not necessarily distinguish between fixed and variable costs.).

176. See 42 U.S.C. $\S 1395 d$ (2006).

177. See 42 U.S.C. $\S 1395 k$ (2006). 
tions or high medical costs can be subject to major cost-sharing expenses. ${ }^{178}$ Given these requirements and limitations on benefits, nearly half of Medicare beneficiaries' health care costs go uncovered. ${ }^{179}$ This has led the Taxation and Health Law Sections of the ABA to acknowledge the position that a hospital's entire Medicare shortfall could count as charity care, given the "elderly constitute a clearly-recognized charitable class." ${ }^{\text {"180 }}$ Moreover, the AHA has stated that because many Medicare beneficiaries are of limited means, they would likely qualify for a hospital's charity care program. ${ }^{181}$ These positions are reinforced by the nearly 8.8 million Medicare beneficiaries designated "dual-eligible" for Medicaid. ${ }^{182}$

Additionally, Medicare payment rates "are set by law rather than through a negotiation process as with private insurers." ${ }^{\text {"183 }}$ Specifically, the Medicare Payment Advisory Commission ("MedPAC") makes annual payment update recommendations to Congress. ${ }^{184}$ This update considers both provider-specific factors (e.g., adequacy of current payments, impact of scheduled policy changes, and anticipated changes in provider costs), as well as the "perspective of the economy-wide gains achieved by the firms and workers who pay taxes that fund Medicare." 185 While MedPAC's use of fixed payments in consideration of the taxpayer's burden is noble, the inability to negotiate reimbursement rates leaves hospitals ill-equipped to respond to budget deficits brought on by changes in patient demand, staffing, etc. ${ }^{186}$

Between 2000 and 2008, Medicare payments also fell significantly relative to costs, and underpayments to hospitals rose from $\$ 1.3$ billion to $\$ 22$ billion. ${ }^{187}$ As a result of this increasing burden, the nationally recog-

178. Jennifer Ryan \& Nora Super, Nat'l Health Pol'y Forum, The George Wash. Univ., NHPF Issue Brief No. 794, Dually Eligible for Medicare and Medicaid: Two FOR ONE OR DOUBLE JEOPARDY 4 (2003), available at http://www.nhpf.org/library/issuebriefs/IB794_Duals_9-30-03.pdf.

179. Id.

180. AM. BAR ASS'N, supra note 156, at 66.

181. Erika Lunder \& Edward C. Liu, Cong. Research Serv., Order Code RL34605, TAX-EXEMPT SECTION 501(C)(3) Hospitals: COMMUNITY BENEFIT STANDARD AND SCHEDULE H 9 (2008), available at http://assets.opencrs.com/rpts/RL34605_20091110.pdf.

182. Teresa Coughlin et al., The Kaiser Family Found., Where Dó- The Burden Lie: Medicaid and Medicare Spending for Dual Eligible Beneficiaries 1 (2009), available at http://www.kff.org/medicaid/upload/7895-2.pdf.

183. AM. Hosp. Ass'N, supra note 174, at 1.

184. See Hearing on MedPAC's Annual March Report to the Congress on Medicare Payment Policy: Hearing Before the Subcommittee on Health of the H. Comm. on Ways and Means, 111th Cong. 4 (2009) [hereinafter MEDPAC Report] (statement of Glenn M. Hackbarth, Chairman of the Medicare Payment Advisory Comm'n.) available at http://frwebgate. access.gpo.gov/cgi-bin/getdoc.cgi?dbname=111_house_hearings\&docid=f:50334.pdf. See generally 42 U.S.C. $\S 1395$ b-6 (2006) (providing for the establishment of the Medicare Payment Advisory Commission).

185. MEDPAC Report, supra note 184, at 4.

186. Telephone Interview with Ken J. Harbaugh, supra note 129.

187. Aм. Hosp. Ass'N, supra note 174, at 3. 
nized Mayo Clinic has implemented a two-year pilot program to assess the financial effect of not accepting Medicare patients. ${ }^{188}$ While MedPAC asserts that annual reimbursement updates provide enough funding to cover the costs of an efficient provider, ${ }^{189}$ aggregate Medicare margins (payments less costs, expressed as a percentage of payments) ${ }^{190}$ have reached a tenyear low, dropping from $6.3 \%$ in 1999 , to $-6.9 \%$ in $2009 .{ }^{191}$ In response, MedPAC states that hospitals facing financial pressure remain able to constrain costs, and that "[o]ver time, aggregate hospital cost growth has moved in parallel with margins on private-payer patients." 192 That being said, MedPAC's arguments do not, by themselves, necessitate exclusion of shortfalls in a definition of charity care.

Finally, CHA has suggested that the provision of services to Medicare beneficiaries is not a factor that differentiates nonprofit hospitals from their for-profit counterparts; as such, the former should not include Medicare losses in a definition of community benefit. ${ }^{193}$ However, this position ignores two key arguments. First, nonprofit hospitals are required to serve Medicare beneficiaries as a condition of tax-exemption, ${ }^{194}$ whereas forprofit hospitals may elect not to participate in the program. ${ }^{195}$ Second, Professor Horwitz's research on managerial behaviors and their impact on access are illustrative of the differences in ownership types; namely, nonprofit hospitals are more likely to provide certain community services regardless of their profitability. ${ }^{196}$ These motivations should be highlighted and rewarded, despite the fact that for-profit hospitals voluntarily choose to provide services to Medicare patients.

188. David Olmos, Mayo Clinic in Arizona to Stop Treating Some Medicare Patients, BloOmBerg News, Dec. 31, 2009, http://www.bloomberg.com/apps/news?pid=20601087\& sid=aHoYSI84VdL0. See also Alec MacGillis, Mayo Clinic Faulted for Limiting Medicare Patients, WASH. Post, Oct. 13, 2009, at A04 (noting that the Glendale facility will require its 3,000 Medicare patients to pay an annual fee of $\$ 250$, plus $\$ 175$ to $\$ 400$ per visit, in order to receive primary care services).

189. MEDPAC Report, supra note 184, at 4.

190. Medicare Payment Advisory Comm'n, Relationships Among Medicare InPATIENT, OVERALl MedicARE AND TOtal MARgins FOR Hospitals 1 (2003).

191. Am. Hosp. Ass'n, American Hospital Association Comments to the Senate Finance Committee on Financing Comprehensive Health Care Reform: Proposed Health System Savings And Revenue Options 3-4 (2009), available at http://www.aha.org/aha/testimony/2009/090526-tes-comments-finance-options.pdf.

192. MEDPAC Report, supra note 184 , at 14.

193. U.S. GOV'T ACCOUNTABILITY OFFICE, supra note 2, at 24.

194. Rev. Rul. 69-545, 1969-2 C.B. 117, available at http://www.irs.gov/pub/irs-tege/rr 69-545.pdf.

195. АM. Hosp. Ass'N, supra note 174, at 1.

196. Horwitz, supra note 10, at 173. 


\section{Community-Building Activities}

Although there is a general consensus within the industry to define community-building activities as "community benefit," the IRS has not yet taken a position. ${ }^{197}$ However Schedule H does allow hospitals to report a number of community building activities (physical improvements and housing; economic development; community support; environmental improvements; leadership development and training for community members; coalition building; community health improvement advocacy; and workforce development). ${ }^{198}$ Despite the IRS's need for additional data on the impact of community building activities, ${ }^{199}$ and suggestions that these activities "represent a relatively small proportion of total operating expenses for hospitals," 200 hospital efforts in this area should not only be included in a definition of community benefit, they should be recognized, rewarded, and encouraged.

First, organizations "created to aid low and moderate income families by lessening neighborhood tensions, eliminating prejudice and discrimination, and combating community deterioration may qualify for exemption under section 501(c)(3) of the [Internal Revenue] Code."201 Such organizations might include those formed to develop home construction or renovation programs for sale to low-income families; ameliorate the housing needs of minority groups; or formulate plans to combat neighborhood blight within a particular area in a city. ${ }^{202}$ Given that the aforementioned community building activities are encouraged by the Code's tax-exemption scheme, it seems reasonable to argue that they should be deemed charitable regardless of the providers' underlying organizational purpose.

Second, a significant body of research exists demonstrating that social determinants can be responsible for systematic disparities in health across diverse populations. ${ }^{203}$ Social determinants are generally defined as "factors in the social environment that influence health . . . [including] income

197. U.S. Gov't ACCOUntabiLity OfFice, supra note 2, at 29.

198. INTERNAL REVENUE SERV., supra note 59.

199. U.S. Gov'T ACCOUNTABILITY OfFICE, supra note 2, at 29-30.

200. Id. at 30 .

201. Rev. Rul. 70-585, 1970-2 C.B. 115, available at http://www.irs.gov/pub/irs-tege/rr 70-585.pdf (alteration in original).

202. Rev. Rul. 70-585, 1970-2 C.B. 115, available at http://www.irs.gov/pub/irs-tege/rr 70-585.pdf.

203. See generally Comm. on Assuring the Health of the Pub. In the 21st, Inst. of Med., The Future of the Public's health in the 21st Century (National Academy Press 2003); Comm. on Using Performance Monitoring to Improve Cmty. Health, Inst. of Med., Improving Health in the Community: A Role for Performance Monitoring (Jane S. Durch et al., eds., National Academy Press 1997); COMM'N ON Soc. Determinants of Health, World Health Org., Closing the Gap in a Generation: Health Equity Through Action on the Social Determinants of Health (2008), available at http://whqlibdoc.who.int/publications/2008/9789241563703_eng.pdf. 
distribution, discrimination, access to education, and housing policies."204 More broadly, they represent "the conditions in which people are born, grow, live, work and age . . .."205 To illustrate the extent of these disparities, there would have been 886,202 fewer deaths in the United States between 1991 and 2000 if African-American and Caucasian mortality rates were equalized. ${ }^{206}$ In contrast, medical advances saved only 176,633 lives during this same period. ${ }^{207}$ While countless others could be provided, this example is indicative of the notion that traditional interventions alone have not sufficiently addressed the root causes of morbidity and mortality.

An emphasis on social determinants of health is not a new phenomenon. In 1974, Canada's Minister of National Health and Welfare suggested that health status could be improved by addressing conditions outside of the traditional health delivery system (i.e., environmental and behavioral threats to health). ${ }^{208}$ Several years later, Great Britain's Department of Health and Social Security published a report that called attention to persisting health inequalities among Britain's fully insured population. ${ }^{209}$ The controversial $^{210}$ "Black Report" suggested these differences were attributable to social inequalities influencing health, and recommended broad policy measures in response. ${ }^{211}$ In 2005, the World Health Organization established a Commission on the Social Determinants of Health to collect evidence and to present strategies for the promotion of health equity. ${ }^{212}$ The Commission's final report, published in 2008, recommended a number of policies to improve living conditions; address the inequitable distribution of power, money and resources; and establish effective measurements to further understand the problem and assess the impact of improvement efforts. $^{213}$

204. Amy J. Schulz et al., Addressing Social Determinants of Health: CommunityBased Participatory Approaches to Research and Practice, 29 Health Educ. Behav. 287, 288 (2002) (alteration in original).

205. Social Determinants of Health, World HeAlth ORG., http://www.who.int/social determinants/en/ (last visited Mar. 2, 2011).

206. COMm'n On Social Determinants of Health, supra note 203, at 30.

207. Id.

208. See generally Marc Lalonde, Minister of Nat'l Health and Welfare, Cat. No. H31-1374, A New Perspective on the Health of Canadians (1974) (Can.), available at http://www.hc-sc.gc.ca/hcs-sss/alt_formats/hpb-dgps/pdf/pubs/1974-lalonde/lalonde-eng .pdf.

209. See generally Sir Douglas Black et Al., The Black Report (1980), reprinted in IneQualities IN HEALTH, at 29 (Peter Townsend \& Nick Davidson eds., Penguin Books, 1992) (1982).

210. See generally Caroline Richmond, Sir Douglas Black: Professor of Medicine Whose Famous Report on Inequality and Health Fell Foul of the Thatcher Government, 325 BMJ 661 (2002) available at http://www.bmj.com/cgi/content/full/325/7365/661/DC1 (describes the controversy surrounding Sir Douglas Black, principal author of the "Black Report").

211. See generally SiR Douglas BlaCK ET AL., supra note 209.

212. See generally Comm'n on Social Determinants of Health, supra note 203.

213. See generally Id. 
In the United States, the Department of Health and Human Services ("HHS") published Healthy People 2000, and later Healthy People 2010, a national health promotion and disease prevention agenda. The latter's objectives focus on health determinants that "encompass the combined effects of individual and community physical and social environments and the policies and interventions used to promote health, prevent disease, and ensure access to quality health care. ${ }^{, 14}$ To accomplish these objectives, HHS emphasizes the use of community building activities. Specifically, activities aimed at addressing a physical environment may target either tangible (e.g., physical hazards in schools or worksites) or intangible (e.g., radiation, ozone, etc.) problems, while those aimed at addressing a social environment may target interpersonal interactions within the community, interactions with social institutions, and other broad areas such as housing, public transportation, and violence in the community. ${ }^{215}$

At least one critic has suggested that additional studies are required to determine the exact correlation between mortality and inequality before establishing new policies. ${ }^{216}$ However, it is impossible to deny the existence of health disparities and the role that social determinants play in their creation and exacerbation. This position is further supported by the attention social determinants have received both nationally and internationally. Given the extent to which many nonprofit hospitals are integrated into the social fabric of their communities, they are in a unique position to actively engage in community building. As such, it is reasonable to include costs associated with these labors in a definition of community benefit, despite their generally being considered non-health related charitable activities.

\section{MAINTAINING IRS CONTROL}

Although critics will likely cite the IRS's troubled past, which has been thoroughly documented elsewhere, ${ }^{217}$ the Agency is in the best posi-

214. U.S. Dep't of Health AND Human Services, Healthy People 2010: UNDERSTANDING AND IMPROVING HEALTH 7 (2000), available at http://www.feddesk.com/ freehandbooks/121505-1.pdf

215. Id. at 19 .

216. See Hugh Gravelle, How Much of the Relation Between Population Mortality and Unequal Distribution of Income is a Statistical Artifact?, 316 BRIT. MED. J. 382 (1998) (arguing that while considerable evidence supports the hypothesis that "holding other factors constant, the higher an individual's income the better is their health," recent analyses demonstarate that "an individual's health is also affected by the distribution of income within society").

217. See generally Joseph J. Thorndike, Annual Regulation of Business Focus: Reorganization of the Internal Revenue Service: Reforming the Internal Revenue Service: A Comparative History, 53 ADMIN. L. REV. 717 (2001) (exploring four key periods of IRS reform, all revolving around complaints of corruption, favoritism, secrecy, and taxpayer mistreatment); Joint COMM. ON TAXATION, JCX-44-04, Description of Present LaW Relating to Charitable and Other EXempt Organizations and Statistical InFormation Regarding Growth AND Oversight of the TAX-EXEMPt SECTOR 37-39 
tion to define a modern community benefit standard. First, the IRS has a number of tools to achieve its policymaking objectives. Specifically, it may issue: 1) regulations pursuant to Congressional directive (i.e., formal rulemaking pursuant to the Administrative Procedure Act); 2) regulations under the IRS's general authority to interpret the Code (i.e., informal rulemaking); 3) revenue rulings (i.e., interpretive rules); and 4) private letter rulings applicable only to the requesting party. ${ }^{218}$ Each of the aforementioned stem from different authority, are issued according to different processes, warrant different standards of judicial deference and, as a result, differ in their degree of applicability and binding effect. ${ }^{219}$ The ability to rely on such an assortment of alternatives allows the IRS to quickly and practically adjust to varying situations, as opposed to waiting on the legislature to reform an unwieldy rule.

In addition, IRS administrators are more likely to have the most sophisticated understanding of complicated tax issues and be in a better position to gather objective information in a less costly manner, as compared to Congress. ${ }^{220}$ For example, the Federal Advisory Committee Act ("FACA") requires that nongovernmental entities providing policy advice to an agency be chartered as a federal advisory committee. ${ }^{221}$ This adds further transparency to agency policymaking, as committees are responsible for holding public meetings, providing advanced public notice of meetings, recording minutes, making documents relied upon in rendering advice publicly available, and making the product of their work publicly available. ${ }^{222}$ Moreover, committees' membership must be "fairly balanced in terms of the points of view represented" and provisions must be established to assure that recommendations are not inappropriately influenced by any special interest. ${ }^{223}$ As such, the FACA insulates federal "agencies politically by providing an ex-

(2004), available at http://www.jct.gov/x-44-04.pdf (noting the number of exempt organization returns reviewed declined by approximately 7,000 between 1993 and 2003). But see Charities and Charitable Giving: Proposals for Reform: Hearing Before the S. Comm. on Fin., 109th Cong. (2005) (statement of Mark W. Everson, Comm'r. of Internal Revenue) (noting increased IRS resources and improved enforcement efforts targeting tax exempt organizations).

218. Bankers Life \& Cas. Co. v. United States, 142 F.3d 973, 978 (7th Cir. 1998).

219. Id. at 978-80. See also Ryan C. Morris, Substantially Deferring to Revenue Rulings After Mead, 2005 BYU L. REV. 999 (2005) (discussing the Internal Revenue Service's authority and means to interpret 26 U.S.C.).

220. See generally Mark Seidenfeld, A Civic Republican Justification for the Bureaucratic State, 105 HARV. L. REV. 1511, 1515 (1992) (noting that "civic republicanism is consistent with broad delegations of political decisionmaking authority to officials with greater expertise and fewer immediate political pressures than directly elected officials or legislators").

221. 5 U.S.C.S. Appx $\S 9$ (LexisNexis 2011).

222. 5 U.S.C.S. Appx § 10(a)-(c) (LexisNexis 2011).

223. 5 U.S.C.S. Appx $§ 5(b)(2)-(3)$ (LexisNexis 2011). See generally Steven P. Croley, Symposium: Public Interested Regulation, 28 FLA. ST. U. L. REV. 7, 39-40 (2000) (providing strong evidence for the independent nature of Federal Advisory Committees). 
ternal, neutral source of expert policy recommendations that can be difficult for legislators and interest groups to ignore or discredit." 224

Finally, the flexibility and expertise outlined above is particularly important given legitimate concerns over the quality of Schedule $\mathrm{H}$ data, especially in early reporting years. While data is expected in late 2010, the need for aggregation may delay its use, and methodological concerns may complicate meaningful comparisons between providers. ${ }^{225}$ In contrast to the IRS, several institutional features make Congress "ill-suited to engage in the experimental, adaptive, trial-and-error approach to policymaking",226 that may be required to make effective use of this data as it becomes available. Specifically, legislative resources are limited, making continuous monitoring of policymaking difficult. ${ }^{227}$ Moreover, revision of legislative policies can be difficult given the need for a congressional majority, as well as "numerous gate keepers and veto-points.",228 As a safeguard, should Congress disapprove of the IRS's policies, it is not without the means to: 1) monitor IRS action through oversight, "watch-dog" committees, or formal investigations; 2) express disapproval of IRS action by denying or reducing appropriations; or 3) amend the current tax code or enact new legislation. ${ }^{29}$

\section{CONCLUSION}

Given declining reimbursement and increasingly competitive markets, hospitals will continue to report charity care figures in amounts less than the aggregate tax benefit they receive. Subsequently, many observers will persist in the belief that these hospitals are not meeting their obligation under $\S 501(\mathrm{c})(3)$. However, this perception is oversimplified, as the IRS standard for determining hospital tax-exempt status is conditioned upon a community benefit requirement, rather than the provision of free care. While subject to significant criticism by State and Federal lawmakers, and arguably subversion by the IRS and the Tax Court, the broad nature of this standard is perhaps its greatest asset. Not only are hospitals in the best position to assess the needs of their communities, such a standard is also practical given the manner in which the U.S. health care system is financed.

224. Croley, supra note 223, at 38-39.

225. See Eileen Salinsky, The Nat'l Health Pol'y Forum, The George Wash. Univ., Issue Brief No. 831, Show Me the Money: The Implications of Schedule H, 12 (2009), available at http://www.nhpf.org/library/issue-briefs/IB831_ShowMetheMoney_0421-09.pdf.

226. Matthew C. Stephenson, Public Regulation of Private Enforcement: The Case for Expanding the Role of Administrative Agencies, 91 VA. L. REV. 93, 140 (2005).

227. Id. at 140 .

228. Id. at 140-141.

229. Matthew Bender \& Company, Inc., Administrative Law $§ 3.02$ (LexisNexis 2010). 
Therefore, in the event that policymakers elect to revise the tax-exemption standard for hospitals, the following considerations are recommended.

First, the standard should exclude fixed charity care percentages, as charity care bears no logical relationship to community need. Such percentages would have a disproportionate effect on certain facilities, and limited information exists to establish a fair formula for assessing community benefit overall. Second, the standard should include bad debt and the unreimbursed cost of Medicare, provided hospitals report such figures as variable costs and adopt improved processes to better identify patients eligible for charity care. Third, the standard should include and encourage community-building activities, as they are already favored under the Code, and they directly address social determinants of health, which is critical to improving population health and addressing growing health disparities. Finally, any future revisions of the community benefit standard should be left to the discretion of the IRS, given its ability to rely on an assortment of policymaking alternatives, as well as expertise both within and without the Agency.

Despite having ended in mid-2009, the economic recession that began two years ago will likely stifle economic growth over the next several years. ${ }^{230}$ This economic challenge is not lost on the health care industry, as Moody's Investors Service reports that the nonprofit health care sector outlook remains negative, and that "hospitals face 'one of the toughest environments in decades" due to "the federal budget deficit; struggling state budgets; weak employer-sponsored insurance and the nation's unemployment rate . . .."231 In addition to this grim economic picture, a recent CMS memorandum failed to provide much hope for hospital finances should the current iteration of health care reform legislation, the Patient Protection and Affordable Care Act ("PPACA"), ${ }^{232}$ be enacted. ${ }^{233}$ All of these factors,

230. See Cong. Budget Office, $111 \mathrm{th}$ Cong., Pub. No. 4095, The Budget And ECONOMIC OUTLOOK: FISCAL YEARS 2010 TO 2020, 23 (2010), available at http://www.cbo.gov/ftpdocs/108xx/doc10871/01-26-Outlook.pdf.

231. Melanie Evans, Moody's Outlook Negative for Not-for-Profits, MODERN HEALTHCARE (Jan. 29, 2010), http://www.modernhealthcare.com/article/20100129/NEWS/ 301299963\#.

232. Patient Protection and Affordable Care Act, H.R. 2590, 111th Cong. (2009), available at $\mathrm{http} / /$ frwebgate.access.gpo.gov/cgi-bin/getdoc.cgi?dbname=111_cong_bills\&docid= f:h3590eas.txt.pdf.

233. Memorandum from Richard S. Foster, Chief Actuary, Centers for Medicare and Medicaid Services, Estimated Financial Effects of the PPACA as Passed by the Senate on December 24, 2009, 8-9 (Jan. 8, 2010) (on file with the Centers for Medicare and Medicaid Services), available at http://www.cms.hhs.gov/ActuarialStudies/Downloads/S_PPACA 2010-01-08.pdf (CMS's chief actuary notes that while the Act would provide Medicaid coverage to an additional thirty-four million uninsured Americans, extend solvency of the Hospital Insurance trust fund an additional ten years, and lower the federal deficit, Medicare payment rates would grow slower than provider costs. As a result, "providers for whom Medicare constitutes a substantive portion of their business could find it difficult to remain profitable and, absent legislative intervention, might end their participation in the program 
coupled with significant increases in health care spending projected through $2019,{ }^{234}$ suggest that the issue of nonprofit hospital tax-exemption will remain increasingly relevant and be further scrutinized by lawmakers, industry groups, patient advocates, and the media for years to come.

\section{ADDENDUM}

On March 23, 2010, President Barack Obama signed into law the PPACA,${ }^{235}$ which along with the Health Care and Education Reconciliation Act of $2010,{ }^{236}$ signed just seven days later, represents the most comprehensive health care legislation in over forty years. Though largely "health insurance reform" in that it seeks to improve access and affordability, the PPACA amends section 501(c)(3) to require that nonprofit hospitals: 1) conduct a community health needs assessment every three years; 2) maintain a written financial assistance policy; 3) limit charges for emergency care provided to patients eligible for financial assistance so as not to exceed the amount charged to patients with insurance; and 4) make reasonable efforts to determine whether a patient is eligible for financial assistance before engaging in extraordinary collection actions. ${ }^{237}$ Hospitals failing to comply with the new requirements may be subject to a $\$ 50,000$ penalty. ${ }^{238}$

Perhaps more notable, the PPACA mandates that the Secretary of the Treasury and the Secretary of HHS "submit to the Committees on Ways and Means, Education and Labor, and Energy and Commerce of the House of Representatives and to the Committees on Finance and Health, Education, Labor, and Pensions of the Senate an annual report" that includes information on all hospitals (i.e., nonprofit, for-profit, and government owned) regarding charity care, bad debt, and the unreimbursed cost of Medicaid and Medicare. ${ }^{239}$ The Secretaries must also conduct a study on costs associated with nonprofit hospitals' community benefit activities, and pro-

(possibly jeopardizing access to care for beneficiaries)." Moreover, simulations suggest that approximately twenty percent of inpatient service providers would become unprofitable within ten years due to productivity adjustments.).

234. See generally Centers for Medicare and Medicaid Services, Department of Health and Human Services, National health Expenditure Projections 2009-2019 (2009), available at http:/www.cms.gov/NationalHealthExpendData/downloads/proj2009 .pdf.

235. Patient Protection and Affordable Care Act, Pub. Law No. 111-148, 124 Stat. 119 (2010), available at http://www.gpo.gov:80/fdsys/pkg/PLAW-111publ148/pdf/PLAW-111 publ148.pdf.

236. Health Care and Education Reconciliation Act of 2010, Pub. Law No. 111-152, 124 Stat. 1029 (2010), available at http://www.gpo.gov:80/fdsys/pkg/PLAW-111publ152/ pdf/PLAW-111publ152.pdf (The Reconciliation Act amended the PPACA to include, among other provisions, an increase in tax credits for individuals to purchase insurance, closure of the Medicare Part D "donut hole" by 2020, and tax subsidies for low income households.).

237. $§ 9007,124$ Stat. at 855-57.

238. § 4959,124 Stat. at $855-57$.

239. Id. at $858-59$. 
vide an additional report, no later than $2015 .{ }^{240}$ Clearly, the PPACA demonstrates Congress' concern with community benefit accountability; however, it also reveals a reluctance to approach the issue in an uncompromising manner (i.e., fixed charity care requirements) and a desire to defer to the expertise of the Department of Treasury and HHS. 
